\title{
EDUKASI KESEHATAN MELALUI MEDIA PERMAINAN ENGKLEK TERHADAP PENGETAHUAN DAN PERILAKU KESEHATAN REPRODUKSI PADA SISWA/SISWI KELAS 5 SDN JAGASATRU I TAHUN 2020
}

\author{
Nabila Irbah ${ }^{1}$, Diyah Sri Yuhandini ${ }^{2}$, Dewi Vimala ${ }^{3}$ \\ Politeknik Kesehatan Tasikmalaya, Jurusan Kebidanan Cirebon \\ e-mail: ${ }^{1}$ nabilairbah4@gmail.com, ${ }^{2}$ diyahsriyuhandini80@gmail.com , \\ 3vimaladewi80@yahoo.com
}

\begin{abstract}
A child is a candidate for the next generation of the nation and national development capital. If children have good qualities such as healthy, smart, physically strong, and productive, they will help support national development for a country. Children's reproductive health is part of overall health, because health problems in children will disrupt the function of reproductive health. Provision of health education is one of the strategies to create healthy and well-behaved children, especially in maintaining reproductive health. This study aims to determine the effect of health education using the traditional game media that has been modified to the level of knowledge and behavior of reproductive health. The study used a quasi-experimental design on 45 elementary school children taken with total sampling technique. Data collection was obtained from primary data using a questionnaire that was analyzed by Repeated ANOVA and McNemar. There is an effect by using the Engklek game on knowledge reproductive health before intervention, after the first intervention, and after the second intervention which is the result showed $p$ value $=0.001(p<0.05)$. Then there is no effect of using Engklek game on the behavior of reproductive health before intervention and after the first intervention the result showed $p$ value $=0.508(p<0.05)$ and there is an effect before intervention and after the second intervention which showed $p$ value $=0.000(p<0.05)$. There is an effect of health education using media playing Engklek on knowledge and behavior in maintaining reproductive health.
\end{abstract}

Keywords: Reproductive health; elementary school children; Engklek games

\begin{abstract}
ABSTRAK
Seorang anak merupakan calon generasi penerus bangsa dan modal pembangunan nasional. Jika anak memiliki kualitas yang baik seperti sehat, cerdas, memiliki fisik tangguh, serta produktif akan membantu menunjang pembangunan nasional bagi suatu negara. Kesehatan reproduksi anak merupakan bagian kesehatan secara keseluruhan, sebab gangguan kesehatan pada anak akan mengganggu fungsi pada kesehatan reproduksi. Pemberian edukasi kesehatan merupakan salah satu strategi mewujudkan anak yang sehat dan berperilaku baik khususnya dalam menjaga kesehatan reproduksi. Penelitian ini bertujuan untuk mengetahui pengaruh edukasi kesehatan menggunakan media permainan tradisional engklek yang telah dimodifikasi terhadap tingkat pengetahuan dan perilaku kesehatan reproduksi. Penelitian menggunakan rancangan quasi experiment pada 45 anak sekolah dasar yang diambil dengan teknik total sampling. Pengumpulan data didapat dari data primer dengan menggunakan kuesioner yang dianalisis dengan uji Repeated ANOVA dan McNemar. Terdapat pengaruh penggunaan media permainan engklek terhadap pengetahuan kesehatan reproduksi sebelum dilakukan permainan, sesudah dilakukan intervensi ke-1, dan sesudah dilakukan intervensi ke-2 menunjukkan nilai $p=0.001(p<0.05)$. Kemudian tidak terdapat pengaruh penggunaan media permainan engklek terhadap perilaku kesehatan reproduksi sebelum dilakukan intervensi dan setelah dilakukan intervensi ke-1 menunjukkan nilai $p=0.508(p<0.05)$ serta terdapat pengaruh pada sebelum dan setelah dilakukan intervensi ke-2 yang menunjukkan nilai $p=0.000(p<0.05)$. Terdapat pengaruh edukasi kesehatan menggunakan media permainan engklek terhadap pengetahuan dan perilaku dalam menjaga kesehatan reproduksi.
\end{abstract}

Kata Kunci: Kesehatan reproduksi; anak sekolah dasar; permainan engklek.

\section{PENDAHULUAN}

\section{Latar Belakang}

Kesehatan reproduksi anak merupakan bagian dari kesehatan pada anak secara keseluruhan, sebab gangguan kesehatan pada anak akan mengganggu fungsi pada sistem reproduksi anak. Kualitas Sumber Daya Manusia (SDM) bagi sebuah negara sangat menentukan untuk berkembangnya suatu negara. Maka dari itu seorang anak merupakan SDM sekaligus calon generasi penerus bangsa dan modal pembangunan nasional, jika anak tersebut memiliki kualitas yang baik 
seperti sehat, cerdas, dan memiliki fisik tangguh serta produktif akan membantu menunjang pembangunan nasional.

Dalam beberapa tahun terakhir kejadian Kekerasan terhadap Anak (KtA) semakin meningkat salah satunya adalah kekerasan seksual yang masuk ke dalam kategori KtA ditunjukkan oleh data dari Official Journal of The American Academy of Pediatrics dengan judul Global Prevalence of Past-year Violence Against Children: A Systematic Review and Minimum Estimates, 2016. Rata-rata 50\% atau diperkirakan lebih dari 1 milyar anak-anak di dunia berusia 2-17 tahun, mengalami kekerasan fisik, seksual, emosional, dan penelantaran di Kawasan Asia sebesar 64\%, Amerika Utara sebesar 56\%, Afrika sebesar 50\%, Amerika Latin sebesar 34\%, Eropa sebesar 12\%, dan Australia sebesar $7 \%$ mengalami kekerasan dalam satu tahun terakhir ${ }^{(1)}$.

Hasil penelitian mengenai kekerasan seksual di Balai Besar Penelitian dan Pengembangan Pelayanan Kesejahteraan Sosial Yogyakarta (B2P3KS) Kementerian Sosial bekerja sama dengan End Child Prostitution, Child Pornography and Trafficking Of Children For Sexual Purposes (ECPAT) Indonesia pada tahun 2017, penelitian dilakukan di Jakarta Timur, Magelang, Yogyakarta, Mataram, dan Makassar. Penelitian dilakukan pada 49 anak yang mengalami kekerasan seksual, penelitian ini melibatkan orang tua, guru, kepala panti, pekerja sosial, dan stakeholder. Lebih dari $50 \%$ kasus kekerasan seksual anak dilakukan oleh anak, pelaku kekerasan seluruhnya berjenis kelamin laki-laki dengan rata-rata usia 16 tahun, $67 \%$ kekerasan seksual dilakukan oleh pelaku melalui paksaan, $30 \%$ bentuk kekerasan yang dilakukan berupa rabaan/sentuhan organ sensitif, dan $26 \%$ hingga hubungan badan, $30,56 \%$ tempat terjadinya kekerasan seksual diantaranya di rumah teman dan $19,4 \%$ dirumah $\operatorname{korban}^{(1)}$.

Ketua Umum Komisi Nasional Perlindungan Anak mengatakan kasus kekerasan terhadap anak di Jawa Barat menduduki posisi tertinggi nomor tiga di Indonesia. Dari 2,1 juta laporan kekerasan selama tahun 2013, 38\% terjadi di Jawa Barat dan dari angka tersebut $52 \%$ adalah kekerasan seksual. Mayoritas pelaku kekerasan seksual dilakukan oleh orang terdekat sang anak, dengan ditunjukkan angka sebesar $82 \%$. Kekerasan terhadap perempuan dan anak di Cirebon masih tinggi. Sepanjang 2018 tercatat ada 137 kasus kekerasan terhadap perempuan dan anak ${ }^{(2)}$.

Seorang anak bukanlah dewasa muda, anakanak menjadi suatu individu unik dengan segala pemikirannya. Maka dari itu seorang anak dalam perkembangannya membutuhkan perhatian dan bimbingan dari orang dewasa salah satu yang terdekat yaitu orang tua dan keluarga. Maslow membagi kebutuhan anak menjadi lima bagian, yaitu kebutuhan fisik, kebutuhan keamanan, kebutuhan kasih sayang, kebutuhan penghargaan, dan kebutuhan aktualisasi diri. Lingkungan keluarga seperti orang tua menjadi sarana pertama dan dekat dengan seorang anak sehingga anak merasa lebih nyaman, terkadang orang tua merasa memberikan pendidikan seks secara dini dianggap hal yang taboo. Maka dari itu, pentingnya orang tua dalam membekali anak untuk dapat bertahan dan melindungi diri dari kekerasan seksual, misalnya dengan menjelaskan pubertas, perkembangan organ reproduksi, anggota tubuh yang boleh dan tidak boleh disentuh.

Perkembangan Ilmu dan Teknologi (IPTEK) mempermudah seseorang mencari yang dibutuhkan, salah satu dampak kemajuan IPTEK adalah seorang anak dapat dengan mudah mengakses internet, bemain gadget menjadi salah satu pilihan orang tua untuk mendiamkan anak yang menangis dan meninggalkan permainan tradisional. Permainan engklek adalah permainan populer pada masa kolonial Belanda bernama Zondaag Mandaag yang kemudian dimainkan oleh anak-anak pribumi berusia 5-12 tahun sehingga semakin meluas ke tanah air. Permainan ini memiliki prosedur dimana pemain harus mengangkat satu kaki dan melompat dengan kaki satu melewati kotak-kotak dalam permainan ini.

Hasil studi pendahuluan yang dilakukan oleh peneliti diketahui bahwa SDN Jagasatru I Kecamatan Pekalipan Kota Cirebon menjadi sekolah dasar dalam wilayah kerja Puskesmas Jagasatru. Pihak Puskesmas mengatakan bahwa di wilayah kerja Puskesmas Jagasatru untuk program puskesmas yang rutin berjalan terhadap kesehatan reproduksi anak Sekolah Dasar (SD) hanya memberikan tablet penambah darah untuk kelas VI sebagai pencegahan anemia. Untuk anak SD belum terpapar mengenai kesehatan reproduksi, karena penyuluhan hanya baru ada untuk remaja di Sekolah Menengah Pertama (SMP). Seorang guru di SDN Jagasatru I mengatakan pernah ada kejadian kekerasan seksual pada tahun 2018 yang dialami siswi kelas VI, pelakunya sendiri adalah orang terdekat yaitu ayah tiri siswi tersebut.

Berdasarkan latar belakang diatas, maka perlu dilakukan penelitian untuk menganalisis pengaruh edukasi kesehatan melalui media permainan tradisional engklek terhadap tingkat pengetahuan dan perilaku kesehatan reproduksi pada siswa/siswi kelas 5 SDN Jagasatru I Kota Cirebon.

\section{Tujuan Penelitian (Opsional)}

\section{Tujuan Umum}

Menganalisis Pengaruh Edukasi Kesehatan Reproduksi Menggunakan Media Permainan Tradisional Engklek Terhadap Tingkat Pengetahuan dan Perilaku Kesehatan Reproduksi Pada Siswa Kelas 5 di SDN Jagasatru I Kecamatan Pekalipan Kota Cirebon Tahun 2020. 


\section{Tujuan Khusus}

a. Untuk mengetahui gambaran pengetahuan sebelum dan sesudah diberikan edukasi dengan media engklek.

b. Untuk mengetahui gambaran perilaku baik dalam menjaga kesehatan reproduksi sebelum dan sesudah diberikan edukasi dengan media engklek.

c. Untuk mengetahui pengaruh media Engklek terhadap tingkat pengetahuan dalam menjaga kesehatan reproduksi.

d. Untuk mengetahui pengaruh media Engklek terhadap perilaku menjaga kesehatan reproduksi.

\section{METODE}

Jenis penelitian kuantitatif menggunakan metode penelitian Quasi Eksperimental one group pretest and post test design. Penelitian ini menganalisis pengaruh permainan engklek edukatif kesehatan terhadap tingkat pengetahuan dan perilaku kesehatan reproduksi pada anak sekolah dasar. Penelitian dilakukan pada bulan Januari sampai Maret 2020 di SDN Jagasatru I Kota Cirebon dengan jumlah sampel ditentukan dengan metode purposive sampling sehingga didapat $45 \mathrm{siswa} / \mathrm{siswi}$. Data dalam penelitian ini merupakan data primer dan proses pengukuran variabel menggunakan instrumen penelitian berupa kuesioner.

Cara pengamatan variabel dilakukan dengan cara membandingkan hasil kuesioner yang telah diberikan secara langsung kepada siswa/siswi SDN Jagasatru I Kota Cirebon sebelum dilakukan edukasi menggunakan media engklek dan sesudah dilakukan interaksi berupa tanya jawab dan penyampaian kesimpulan dari bermain engklek edukatif tersebut. Pengamatan variabel pengetahuan dan perilaku mengenai menjaga kesehatan reproduksi diukur sebanyak 3 kali yaitu sebelum pemberian edukasi media engklek, setelah pemberian edukasi pertama dan setelah pemberian edukasi kedua, yang dilakukan oleh peneliti dibantu dengan 3 orang enumerator. Hipotesis kerja dalam penelitian, ada pengaruh pemberian edukasi kesehatan menggunakan media permainan engklek terhadap tingkat pengetahuan dan perilaku kesehatan reproduksi siswa/siswi kelas 5 SDN Jagasatru I Kota Cirebon. Uji statistik menggunakan uji Repeated ANOVA untuk mengukur rata-rata pengetahuan dengan media engklek serta McNemar untuk mengetahui pengaruh edukasi kesehatan menggunakan media engklek terhadap perilaku.

\section{HASIL}

Berdasarkan hasil penelitian yang dilakukan di SDN Jagasatru I Kota Cirebon tahun 2020 mengenai pengaruh edukasi kesehatan reproduksi menggunakan media permainan tradisional engklek terhadap tingkat pengetahuan dan perilaku kesehatan reproduksi, maka diperoleh sebagai berikut:

\section{A. Karakteristik responden}

Tabel 2

Distribusi Frekuensi Karakteristik Responden SDN Jagasatru I Kota Cirebon Tahun 2020

\begin{tabular}{ccc}
\hline Variabel & Frekuensi & Persentase(\%) \\
\hline Jenis Kelamin & & \\
Laki-laki & 19 & 42.2 \\
Perempuan & 26 & 57.8 \\
Usia & & \\
10 Tahun & 10 & 22.2 \\
11 Tahun & 35 & 87.8 \\
\hline
\end{tabular}

Sumber: Data Primer Tahun 2020

Berdasarkan Tabel 2 dapat diketahui bahwa sebagian besar responden berjenis kelamin perempuan yaitu sebanyak 26 orang dengan persentase $57.8 \%$. Untuk usia responden mayoritas berusia 11 tahun yaitu sebanyak 35 orang dengan persentase $87.8 \%$.

\section{B. Analisis Univariat}

Tabel 4

Gambaran Pengetahuan Responden Mengenai Kesehatan Reproduksi Sebelum, Setelah Permainan Ke-1 dan Setelah Permainan Ke-2 Engklek Edukatif

\begin{tabular}{cccc}
\hline Pengetahuan & Mean & Standar Deviasi & Min - Max \\
\hline Pre-test & 14.13 & 2.201 & $8-19$ \\
Post-test 1 & 14.73 & 1.776 & $11-19$ \\
Post-test 2 & 15.07 & 1.802 & $11-20$ \\
\hline
\end{tabular}

Sumber: Data Primer Tahun 2020

Berdasarkan Tabel 4 dapat diketahui bahwa terdapat peningkatan rata-rata pengetahuan dari sebelum diberikan intervensi dan sampai dilakukan post-test intervensi yang kedua. Dimana gambaran pengetahuan responden sebelum diberikan intervensi dan dari hasil kuesioner dengan skala penilaian 0 sampai 20, diketahui bahwa pengetahuan responden sebelum diberikan intervensi memiliki rata-rata skor 14.13, setelah intervensi pertama rata-rata menjadi 14.73, kemudia rata-rata meningkat setelah intervensi kedua menjadi 15.07 .

Tabel 5

Gambaran Responden Berdasarkan Perilaku Menjaga Kesehatan Reproduksi Sebelum Setelah Permainan Ke-1 dan Setelah Permainan Ke-2 Engklek Edukatif 


\begin{tabular}{ccccccc}
\hline \multirow{2}{*}{ Pemberian } & \multicolumn{3}{c}{ Perilakil } & \multicolumn{2}{c}{ Total } \\
Intertensi & \multicolumn{2}{c}{ Baik } & \multicolumn{2}{c}{ Kurang Baik } & \multicolumn{2}{c}{} \\
& $\mathrm{N}$ & $\%$ & $\mathrm{~N}$ & $\%$ & $\mathrm{~N}$ & $\%$ \\
\hline Pre-test & 11 & 24.4 & 34 & 75.6 & 45 & 100 \\
Posit-test Ke-1 & 14 & 31.1 & 31 & 68.9 & 45 & 100 \\
Post-test Ke-2 & 28 & 62.2 & 17 & 37.8 & 45 & 100 \\
\hline
\end{tabular}

Sumber: Data Primer Tahun 2020

Berdasarkan Tabel 5 dapat diketahui bahwa terdapat peningkatan perilaku baik dari sebelum diberikan intervensi dan sampai dilakukan post-test intervensi yang kedua. Dimana pada saat sebelum dilakukan permainan engklek sebagai media intervensi, sebagian besar responden memiliki perilaku menjaga kesehatan reproduksi kurang baik yaitu dengan persentase sebesar $75.6 \%$. Setelah intervensi pertama persentase perilaku kurang baik menurun menjadi $68.9 \%$ kemudian setelah dilakukan intervensi kedua perilaku kurang baik menurun menjadi $37,8 \%$ dan persentase perilaku baik sebesar $62.2 \%$.

\section{Analisis Bivariat}

\section{Uji Repeated ANOVA}

Tabel 6

Pengaruh Permainan Engklek Terhadap Perubahan Pengetahuan Mengenai Kesehatan Reproduksi Sebelum, Setelah Permainan ke-1, dan Setelah Permainan Ke-2 Engklek Edukatif

\begin{tabular}{ccccc}
\hline \multicolumn{2}{c}{ Pengetahuan } & $\begin{array}{c}\text { Perbedan Rata- } \\
\text { rata }\end{array}$ & $\begin{array}{c}\rho \\
\text { Value }\end{array}$ & $\begin{array}{c}\text { Greenhouse- } \\
\text { Geisser Sig. }\end{array}$ \\
\hline \multirow{2}{*}{ Pre-test } & Post-test Ke-1 & -0.600 & 0.102 & \\
& Post-test Ke-2 & $-0.933^{*}$ & 0.000 & \\
Post-test Ke-1 & Pre-test & 0.600 & 0.102 & \multirow{2}{*}{0.001} \\
& Post-test Ke-2 & -0.333 & 0.424 & \\
\multirow{2}{*}{ Post-test Ke-2 } & Pre-test & $0.933^{*}$ & 0.000 & \\
& Post-test Ke-1 & 0.333 & 0.424 & \\
\hline
\end{tabular}

Sumber: Uji Repeated ANOVA

Berdasarkan Tabel 6 dapat diketahui bahwa perbedaan rata-rata skor pengetahuan sebelum dilakukan intervensi permainan engklek dengan setelah dilakukan permainan engklek ke-1 dengan selisih -0.600 (CI 95\%). Didapat pula nilai Greenhouse-Geisser Sig. Sebesar 0.001 (P < 0.05).

\section{Uji Mc Nemar}

\section{Tabel 7}

Pengaruh Permainan Engklek Terhadap Perubahan Perilaku Mengenai Menjaga

\section{Kesehatan Reproduksi Sebelum Bermain Dengan Setelah Bermain Ke-1}

\begin{tabular}{|c|c|c|c|c|c|c|c|}
\hline \multirow{3}{*}{ Pre-test } & \multicolumn{4}{|c|}{ Post-test ke-1 } & \multirow{2}{*}{\multicolumn{2}{|c|}{ Total }} & \multirow{3}{*}{$\begin{array}{c}\rho \\
\text { Value }\end{array}$} \\
\hline & \multicolumn{2}{|c|}{ Baik } & \multicolumn{2}{|c|}{ Kurang Baik } & & & \\
\hline & $\mathrm{N}$ & $\%$ & $\mathrm{~N}$ & $\%$ & $\mathrm{~N}$ & $\%$ & \\
\hline Baik & 8 & 17.8 & 3 & 6.7 & 11 & 24.4 & 0.508 \\
\hline Kurang baik & 6 & 13.3 & 28 & 62.2 & 34 & 75.6 & \\
\hline Total & 14 & 31.1 & 31 & 68.9 & 45 & 100 & \\
\hline
\end{tabular}

Sumber: Uji McNemar

Berdasarkan Tabel 7 menunjukkan bahwa dari 11 responden yang memiliki perilaku baik mengenai menjaga kesehatan reproduksi sebelum bermain engklek, 8 orang atau $17.8 \%$ tetap memiliki perilaku positif mengenai menjaga kesehatan reproduksi dan 3 orang atau $6.7 \%$ memiliki perilaku kurang baik setelah bermain engklek pertama. Untuk 34 responden yang memiliki perilaku kurang baik mengenai menjaga kesehatan reproduksi sebelum dilakukan permainan engklek, sebanyak 6 orang atau 13.3\% memiliki perilaku baik dalam menjaga kesehatan reproduksi dan sebanyak 28 orang atau persentase sebesar $62.2 \%$ tetap memiliki perilaku yang kurang baik dalam menjaga kesehatan reproduksi setelah dilakukan permainan engklek pertama.

Tabel 8

Pengaruh Permainan Engklek Terhadap

Perubahan Perilaku Mengenai Menjaga Kesehatan Reproduksi Sebelum Bermain Dengan Setelah Bermain Ke-2

\begin{tabular}{|c|c|c|c|c|c|c|c|}
\hline \multirow{3}{*}{ Pre-test } & \multicolumn{4}{|c|}{ Post-test ke-2 } & \multirow{2}{*}{\multicolumn{2}{|c|}{ Total }} & \multirow{3}{*}{$\begin{array}{c}\rho \\
\text { Value }\end{array}$} \\
\hline & \multicolumn{2}{|c|}{ Baik } & \multicolumn{2}{|c|}{ Kurang Baik } & & & \\
\hline & $\mathbf{N}$ & $\%$ & $\mathbf{N}$ & $\%$ & $\mathbf{N}$ & $\%$ & \\
\hline Baik & 11 & 24.4 & 0 & 0 & 11 & 24.4 & 0.000 \\
\hline Kurang baik & 17 & 37.8 & 17 & 37.8 & 34 & 75.6 & \\
\hline Total & 28 & 62.2 & 17 & 37.8 & 45 & 100 & \\
\hline
\end{tabular}

Sumber: Uji McNemar

Berdasarkan Tabel 8 menunjukkan bahwa dari 11 responden yang memiliki perilaku baik dalam menjaga kesehatan reproduksi sebelum bermain engklek, seluruhnya yaitu sebanyak 11 orang atau $24.4 \%$ tetap memiliki perilaku yang baik dan tidak ada responden yang memiliki perilaku kurang baik setelah dilakukan permainan engklek yang kedua. Untuk 34 responden yang memiliki perilaku kurang baik dalam menjaga kesehatan reproduksi sebelum bermain engklek, 17 orang atau $37.8 \%$ memiliki perilaku baik dan sebagian lainnya yaitu sebanyak 17 orang tetap memiliki perilaku 
kurang baik setelah dilakukan permainan engklek yang kedua.

Tabel 9

Pengaruh Permainan Engklek Terhadap Perubahan Perilaku Mengenai Menjaga Kesehatan Reproduksi Setelah Bermain Ke-1 Dengan Setelah Bermain Ke-2

\begin{tabular}{|c|c|c|c|c|c|c|c|}
\hline \multirow{3}{*}{ Posi-test ke-l } & \multicolumn{4}{|c|}{ Poss-titest ke-2 } & \multirow{2}{*}{\multicolumn{2}{|c|}{ Total }} & \multirow{3}{*}{$\begin{array}{c}\rho \\
\text { Value }\end{array}$} \\
\hline & \multicolumn{2}{|c|}{ Baik } & \multicolumn{2}{|c|}{ Kurang Baik } & & & \\
\hline & $\mathrm{N}$ & $\%$ & $\mathrm{~N}$ & $\%$ & $\mathrm{~N}$ & $\%$ & \\
\hline Baik & 13 & 28.9 & 1 & 2.2 & 14 & 31.1 & \\
\hline Kurang baik & 15 & 33.3 & 16 & 35.6 & 31 & 68.9 & 0.001 \\
\hline Total & 28 & 62.2 & 17 & 37.8 & 45 & 100 & \\
\hline
\end{tabular}

Sumber: Uji McNemar

Berdasarkan Tabel 9 menunjukkan bahwa dari 14 responden yang memiliki perilaku baik dalam menjaga kesehatan reproduksi setelah bermain engklek pertama, mayoritas yaitu sebanyak 13 orang atau $28.9 \%$ tetap memiliki perilaku yang baik dan 1 orang responden yang memiliki perilaku kurang baik setelah dilakukan permainan engklek yang kedua. Untuk 31 responden yang memiliki perilaku kurang baik dalam menjaga kesehatan reproduksi setelah bermain engklek pertama, 15 orang atau $33.3 \%$ memiliki perilaku baik dan sebagian lainnya yaitu sebanyak 16 orang tetap memiliki perilaku kurang baik setelah dilakukan permainan engklek yang kedua.

\section{PEMBAHASAN}

Dari penelitian yang sudah dilakukan memperlihatkan bahwa terdapat peningkatan rata-rata yang signifikan antara sebelum dilakukan intervensi dan sesudah dilakukan intervensi pertama. Dari hasil penelitian didapatkan bahwa perbedaan rata-rata pengetahuan pre-test dan post-test ke-1 menggunakan uji Repeated ANOVA diperoleh $\mathrm{P}$ value 0.102 dengan tingkat kepercayaan $(\alpha)$ 5\%. Artinya tidak terdapat pengaruh edukasi kesehatan melalui media permainan engklek terhadap perubahan pengetahuan mengenai kesehatan reproduksi setelah dilakukan permainan ke1.

Hasil yang signifikan ditunjukkan pada perhitungan statistik sebelum dilakukan permainan engklek dengan setelah dilakukan permainan engklek ke-2 dengan jarak 2 minggu yang menghasilkan $P$ value 0.000 dengan tingkat kepercayaan $(\alpha)$ 5\%. Artinya terdapat pengaruh edukasi kesehatan melalui media permainan engklek terhadap perubahan pengetahuan mengenai kesehatan reproduksi setelah dilakukan permainan ke-2.

Berdasarkan Uji Repeated ANOVA didapat nilai Greenhouse-Geisser Sig. sebesar 0.001 ( $\mathrm{P}<0.05)$, memiliki makna bahwa terdapat pengaruh edukasi kesehatan melalui media permainan engklek terhadap perubahan pengetahuan mengenai kesehatan reproduksi.

Peningkatan rata-rata tersebut memiliki arti sebagai hasil dari pendidikan atau edukasi kesehatan yang diberikan sebagai bentuk intervensi menunjukkan adanya perbedaan yang bermakna. Hasil ini pula menunjukkan bahwa pemberian pendidikan kesehatan yang dilakukan secara singkat akan berdampak positif dalam meningkatkan pengetahuan seseorang ${ }^{(3)}$.

Peningkatan tersebut diartikan sebagai hasil dari pemberian edukasi kesehatan dengan alat bantu berupa media permainan engklek yang telah dimodifikasi. Faktor-faktor yang mempengaruhi mudah ditangkapnya materi pembelajaran oleh seseorang atau masyarakat adalah melalui berbagai macam alat bantu pendidikan. Tetapi masing-masing alat mempunyai intensitas yang berbeda-beda di dalam membantu permasalahan seseorang. Elgar Dale membagi alat peraga tersebut menjadi 11 macam, dan sekaligus menggambarkan tingkat intensitas tiap-tiap alat tersebut dalam sebuah kerucut. Dari kerucut Edgar Dale dapat dilihat bahwa lapisan yang paling dasar adalah benda asli dan yang paling atas adalah katakata. Hal ini berarti bahwa dalam proses pendidikan, benda asli mempunyai intensitas paling tinggi untuk mempersepsikan bahan pendidikan atau pengajaran. Sedangkan penyampaian bahan yang hanya dengan kata-kata saja sangat kurang efektif atau intensitasnya paling rendah ${ }^{(4)}$.

Permainan engklek menjadi sebuah media pembelajaran untuk menambah pengetahuan responden mengenai kesehatan reproduksi. Permainan engklek termasuk dalam pembelajaran dengan pemberian simulasi dimana simulasi menurut Supariasa (2013) disitasi ${ }^{(9)}$, metode simulasi adalah permainan yang direncanakan yang maknanya dapat diambil untuk kepentingan sehari-hari. Metode simulasi dapat dilaksanakan untuk memaknai masalah hubungan antar-manusia. Keunggulan metode simulasi adalah partisipasi peserta dalam suatu kegiatan, peserta langsung mengalami dan berbuat, suasana lebih santai dan peserta dapat memahami permasalahan dalam kehidupan sehari-hari, dan permainan akan menimbulkan kesan yang mendalam.

Dalam permainan engklek memuat materi diantaranya pengertian dan tugas seorang lelaki dan perempuan dengan tujuan responden memahami istilah tentang jenis kelamin dan gender yang sesuai dengan pemahaman usia responden, menstruasi dan mimpi basah agar responden memahami dan adanya kesiapan terhadap pertumbuhan sekunder yang terjadi pada perempuan dan laki-laki, cara menjaga kebersihan organ genitalia dengan tujuan responden memahami kebersihan secara dasar untuk mengurangi kejadian penyakit berkaitan dengan kesehatan reproduksi, serta sentuhan boleh dan tidak boleh bertujuan agar responden dapat mencegah terjadinya kasus pelecehan seksual. Penggunaan media engklek menjadi salah satu 
strategi yang efektif dalam memberikan edukasi kesehatan khususnya untuk meningkatkan pengetahuan terhadap kesehatan reproduksi anak usia sekolah dasar.

Pemberian edukasi menggunakan media permainan engklek untuk mendapatkan peningkatan pengetahuan bermakna dilakukan secara berulang sehingga pemahaman anak tentang kesehatan reproduksi menjadi baik. Meningkatnya pengetahuan adalah hasil positif dari sebuah proses pembelajaran anak. Pertumbuhan intelektual anak mengandung tiga aspek yaitu struktur, content, dan function. Anak yang sedang mengalami perkembangan, struktur, dan konten intelektualnya berubah/berkembang. Fungsi dan adaptasi akan tersusun sehingga melahirkan suatu rangkaian perkembangan, masing-masing mempunyai struktur psikologi khusus yang menentukan kecakapan pikiran anak. Maka, Piaget mengartikan intelegensi adalah sejumlah struktur psikologis yang ada pada tingkat perkembangan khusus (Dalyono, 2012 $\left.\operatorname{disitasi}^{34}\right)$.

Dari hasil penelitian yang telah dilakukan, untuk mengetahui adanya perbedaan proporsi perilaku menjaga kesehatan reproduksi sebelum dilakukan permainan engklek dan sesudah dilakukan permainan engklek ke-1 dengan jarak 1 minggu menggunakan uji statistic McNemar, diperoleh hasil $\mathrm{P}$ value 0.508 dengan tingkat kepercayaan $(\alpha)$ 5\%. Artinya tidak terdapat pengaruh edukasi kesehatan melalui media permainan engklek terhadap perubahan perilaku menjaga kesehatan reproduksi setelah permainan engklek ke-1 dilaksanakan.

Perilaku merupakan respon/reaksi seorang individu terhadap stimulus yang berasal dari luar maupun dari dalam dirinya ${ }^{(4)}$. Sedangkan menurut Wawan $^{(22)}$ Perilaku merupakan suatu tindakan yang dapat diamati dan mempunyai frekuensi spesifik, durasi dan tujuan baik disadari maupun tidak. Jadi perilaku adalah proses yang dapat disadari maupun tidak yang bersifat individual tergantung pada seseorang tersebut. Perilaku Menurut teori Lawrance Green dan kawan-kawan ${ }^{(8)}$ menyatakan bahwa perilaku manusia dipengaruhi oleh tiga faktor pokok, yaitu faktor predisposisi (Predisposing factors), faktor yang mendukung (enabling factors) dan faktor penguat (reinforcing factors). Dalam perubahan perilaku membutuhkan stimulus terus-menerus sehingga menghasilkan respon atau reaksi yang benar oleh individu.

Hasil yang berbeda ditunjukkan pada perhitungan statistik sebelum dilakukan permainan engklek dengan sesudah dilakukan permainan engklek ke-2 dengan jarak 2 minggu, memperoleh hasil $\mathrm{P}$ value 0.000 dengan tingkat kepercayaan $(\alpha)$ 5\%. Artinya terdapat pengaruh edukasi kesehatan melalui media permainan engklek terhadap perubahan perilaku menjaga kesehatan reproduksi setelah dilakukan permainan engklek ke-2. Hal ini didukung pula dari perhitungan statistik setelah permainan engklek ke-1 dan setelah permainan engklek ke-2 dengan jarak 1 minggu, memperoleh hasil minggu, memperoleh hasil $\mathrm{P}$ value 0.001 dengan tingkat kepercayaan $(\alpha) 5 \%$. Artinya terdapat pengaruh edukasi kesehatan melalui media permainan engklek terhadap perubahan perilaku menjaga kesehatan reproduksi setelah dilakukan permainan engklek ke-1 dan ke-2.

Hasil penelitian menunjukkan bahwa perubahan perilaku yang membutuhkan waktu singkat hanya 1 minggu setelah dilakukannya intervensi pertama sehingga terjadinya perilaku kearah baik antara lain perilaku dalam membersihkan kemaluan (cebok) dengan tepat untuk menghindari penyakit, bermain bebas pada malam hari, menolak disentuh di bagian tubuh pribadi, menolak diajak ke tempat sepi oleh siapapun. Membutuhkan waktu 2 minggu untuk terjadinya perubahan perilaku kearah baik diantaranya yaitu tidak menyentuh organ pribadi teman sebaya dan tidak membaca buku yang mengandung pornografi. Sedangkan perubahan perilaku kearah baik yang membutuhkan waktu lebih lama adalah menonton film atau video yang mengandung pornografi.

Hal ini sesuai dalam buku Narkoba Milenium Baru yang ditulis oleh Kastleman ${ }^{(35)}$ dimana otak terus menerus menjadi semakin tidak peka terhadap jenis gambar pornografi yang sama. Hal ini yang membuat kecanduan dan para pecandu untuk mengubah atau menambah jenis dan tingkatan gambar yang ia tonton. Dalam buku ini disebutkan untuk mengurangi dan melindungi remaja dari bahaya kecanduan pornografi yaitu dengan latihan fisik setidaknya dua puluh menit, jaga diri dengan melakukan perawatan diri setiap hari secara konsisten, dan jangan takut untuk gagal.

Berdasarkan teori H.L Bloom disitasi dalam ${ }^{(23)}$ mengenai perilaku dalam menjaga kesehatan dapat dipengaruhi oleh empat faktor, yaitu pertama adalah faktor keturunan, faktor ini lebih mengarah pada kondisi individu seorang responden yang berkaitan dengan asal usul keluarga, ras, dan jenis golongan darah. Kedua, dipengaruhi oleh pelayanan kesehatan, faktor ini dipengaruhi oleh seberapa jauh pelayanan kesehatan yang diberikan oleh tenaga kesehatan dan didapat oleh responden. Ketiga, faktor gaya hidup, faktor yang dapat mempengaruhi perubahan perilaku berhubungan dengan kebiasaan seorang individu atau masyarakat. Keempat, faktor lingkungan sangat besar dalam perubahan perilaku menjaga dan status kesehatan. Kemudian faktor lingkungan terdiri dari tiga bagian yaitu lingkungan secara fisik seperti yang sudah dijelaskan pada pembahasan pengetahuan mengenai lingkungan tempat penelitian. Lingkungan biologis, yaitu orang-orang yang berada di sekitar responden hal ini dapat mempengaruhi perubahan perilaku anak dalam menjaga kesehatan reproduksi. Lingkungan sosial, lingkungan ini adalah bentuk lain secara fisik dan biologis dimana jika seorang anak bergaul dengan teman sebaya atau orang dewasa yang 
memiliki kebiasaan menjaga kesehatan reproduksi dengan baik maka anak tersebut akan memiliki perilaku baik dalam menjaga kesehatan reproduksi. Karena lingkungan bukan hanya sekedar berkaitan dengan alam saja, tetapi segala sesuatu yang ada di sekeliling anak dalam setiap keadaan yang sedang dihadapi seperti lingkungan keluarga, sekolah, masyarakat, dan lain sebagainya.

Dari hasil penelitian dapat diketahui bahwa perubahan perilaku bermakna didapat setelah dilakukan intervensi ke-1 dengan jarak 2 minggu dari pre-test dan intervensi ke-2 dimana memiliki jarak 3 minggu dari sebelum diberikan intervensi, hal ini sejalan dengan penelitian yang dilakukan oleh Philippa Lally dari Universitas London disitasi dalam ${ }^{(36)}$ dikatakan 21 hari merupakan tahap latihan dan penguatan menuju pemantapan perilaku menuju menjadi kebiasaan baik.

Sehingga dapat disimpulkan bahwa media permainan engklek dapat digunakan sebagai alternatif untuk memberikan edukasi kesehatan secara berkala dengan jarak minimum 2-3 minggu. Pemberian edukasi menggunakan media engklek dinilai lebih efektif untuk merubah perilaku anak sekolah dasar menuju remaja. Hal ini sesuai dengan karakteristik anak sekolah dasar dimana mempunyai rasa ingin tahu, ingin belajar yang tinggi serta pada masa ini gemar membentuk kelompok sebaya, biasanya untuk dapat bermain bersama-sama sehingga dapat mempengaruhi perubahan pengetahuan kemudian perubahan perilaku yang disadari kearah yang lebih baik dan baru.

\section{KESIMPULAN}

Berdasarkan hasil penelitian dan pembahasan yang telah diuraikan, maka peneliti dapat memberikan kesimpulan sebagai berikut

Sebelum dilakukan edukasi kesehatan menggunakan media permainan engklek edukatif dapat diketahui hampir sepertiga responden memiliki pengetahuan dibawah rata-rata. Mengalami peningkatan rata-rata skor pengetahuan dari sebelum intervensi, sesudah intervensi pertama dan sesudah intervensi kedua. Sebelum dilakukan edukasi kesehatan menggunakan media permainan engklek edukatif dapat diketahui sebagian besar responden memiliki perilaku kurang baik dalam menjaga kesehatan reproduksi. Terdapat peningkatan perilaku baik setelah dilakukan permainan engklek edukatif dalam menjaga kesehatan reproduksi.

Terdapat pengaruh edukasi kesehatan menggunakan media permainan engklek edukatif terhadap peningkatan pengetahuan mengenai kesehatan reproduksi sebelum dan sesudah permainan engklek. Tidak terdapat perbedaan perilaku bermakna antara sebelum diberikan intervensi dengan sesudah diberikan intervensi ke-1. Perbedaan perilaku yang bermakna ditemukan antara perilaku sebelum diberikan intervensi dengan perilaku sesudah diberikan intervensi yang ke-2, dan ditemukan perbedaan perilaku bermakna sesaat sesudah intervensi maupun satu minggu setelah diberikan intervensi.

\section{DAFTAR PUSTAKA}

1. Mardina R. Kekerasan Terhadap Anak dan Remaja. Jakarta: Kemenkes RI; 2016. p. 1-11.

2. Baehaqi AI. Sepanjang 2018, Ada 137 Kasus Kekerasan Terhadap Perempuan dan Anak di Wilayah III [Internet]. Tribun Jabar. 2018. p. 1. Available from: https://bit.ly/30spXPD

3. Anonim. Anak, Hak-hak Anak dan Perlindungan Hukum Terhadap Anak. 2010;8(3):14-47.

4. Goble FG. Mazhab Ketiga Psikologi Humanistik Abraham Maslow. In: Mazhab Ketiga Psikologi Humanistik Abraham Maslow. 15th ed. Yogyakarta: KANISUS; 2010. p. 69-94.

5. Hidayatullah A. Upaya menumbuhkan kreativitas anak dengan permainan matematika. J Pedagog. 2016;2:58-64.

6. Fitri ND, Hariyani IT. Pengembangan Permainan Engklek Modern Untuk Meningkatkan Kemampuan Fisik Motorik Anak Usia Dini Sebagai Upaya Mengurangi Kecanduan Game di Smartphone. 2016;(4):540-55.

7. Fitriyah A, Khaerunisa I, Arabia S, Timss B. Pengaruh Penggunaan Metode Drill Berbantuan Permainan Engklek Termodifikasi terhadap Kemampuan Pemecahan Masalah Siswa Kelas VII yang diajarkan akan bertahan lama di latihan . Salah satu metode pembelajaran metode pembelajaran yang menekankan Metode ini menyajikan masalah dalam bentuk latihan soal pada tingkat. 2018;2(2):267-77.

8. Wandini RR, Rafi A. Belajar Mengenal Bangun Datar Dengan Menggunakan Permainan Tradisional Engklek / Engkrang. Pendidik Islam dan Teknol Pendidik. 2018; VIII:1-12.

9. Wulandari A, Herawati. Pengaruh Penggunaan Kartu UNO Sebagai Media Permainan Tentang Buah dan Sayur Pada Anak Sekolah Dasar Di SDN Brosot dan SDN Prembulan Galur Kulonprogo. Poltekkes Kemenkes Yogyakarta. 2018;(2):9-24.

10. Arsyad A. Media Pembelajaran. Jakarta: PT Rajagrafindo Persada; 2013.

11. Dewi DM. Meningkatkan Pengetahuan Pendidikan Seks Melalui Layanan Informasi Pada Siswa Kelas VI Madrasah Ibtidaiyah Negeri Sumurrejo Kota Semarang Tahun Ajaran 2015/2016. 2016;

12. Tjahjono S, Widodo M, Nita V. Pencegahan Bullying di Sekolah Dasar melalui Pendidikan Kesehatan Reproduksi Bullying Prevention in Elementary School through Reproductive Health Education Bullying adalah bahasa Inggris. J Komun Pendidik. 2019;3(1):67-75.

13. Rohimah CI, Solehati T, Windani C, Sari M. Pengaruh Pengetahuan, Sikap dan Tindakan Siswi Sekolah Dasar Terkait Genitalia Hy- giene. 
2019;4(1)

14. Lestari W, Wulansari S. Pertunjukan Wayang Interaktif Sebagai Sarana Promosi Kesehatan Remaja Tentang Rokok, Narkoba, dan Pergaulan Bebas. Bul Penelit Sist Kesehat. 2018;21(April):125-32.

15. Pinem S. Kesehatan Reproduksi dan Kontrasepsi. Cetakan Pe. Wijaya N, editor. Jakarta: Trans Info Media; 2009.

16. Wirdhana I, Muin E, Witri W, Nuranti A. Kurikulum Diklat Teknis Pengelolaan PIK Remaja/Mahasiswa Bagi Pengelola, Pendidik Sebaya, Dan Konselor Sebaya PIK Remaja/Mahasiswa. Cetakan Ke. Jakarta: Badan Kependudukan dan Keluarga Berencana Nasional; 2014.

17. Kemendikbud. Ilmu Pengetahuan Alam (IPA) Modul 2 Mengenal Fase Kehidupan Manusia. 2018;

18. Notoatmodjo S. Kesehatan Masyarakat Ilmu \& Seni. Jakarta: Rineka Cipta; 2011.

19. Herwati, Muchtar M. Model Pendidikan Kesehatan Terhadap Pengetahuan dan Sikap Dalam Kesiapan Menghadapi Menarche di Sekolah Dasar. Menara Ilmu. 2017;XI(75):16775.

20. Notoatmodjo S. Promosi Kesehatan \& Perilaku Kesehatan. Jakarta: Rineka Cipta; 2012.

21. Fitriani. Hubungan Pendidikan Seks dengan Perilaku Seksual Pada Remaja di SMK Prayatna1 Medan. USU. 2011;

22. Wawan A, Dewi M. Teori dan Pengukuran Pengetahuan, Sikap, dan Perilaku Manusia. Cetakan Ke. Yogyakarta: Nuha Medika; 2011.

23. Fitriany SM, Farouk H, Taqwa R. Perilaku Masyarakat dalam Pengelolaan Kesehatan Lingkungan (Studi di Desa Segiguk sebagai Salah Satu Desa Penyangga Kawasan Hutan Suaka Margasatwa Gunung Raya Ogan Komering Ulu Selatan). J Penelit Sains. 2016;18:41-6.

24. Notoatmodjo S. Metodologi Penelitian Kesehatan. Cetakan Ke. Jakarta: PT Rineka Cipta; 2018.

25. Sugiyono. Metode Penelitian Kuantitatif, Kualitatif, dan R\&D. Cetakan ke. Bandung: Alfabeta; 2017.

26. Arikunto S. Prosedur Penelitian Suatu Pendekatan Praktik. Edisi Revi. Jakarta: PT Rineka Cipta; 2010.

27. Dahlan MS. Statistik Untuk Kedokteran dan Kesehatan. 6th ed. Kurniawan W, editor. Jakarta: Epidemiologi Indonesia; 2014. 149-155 p.

28. Pragita RR, Purwandari R, Sulistyorini L. Pengaruh Pendidikan Kesehatan Metode Strategem dengan Media Audiovisual Terhadap Pengetahuan Kesehatan Reproduksi Remaja. Indones J Heal Sci. 2018;016(September).

29. Dewiani K, Purnama Y, Yusanti L. Pendidikan Seks Dini Dan Kesehatan Reproduksi Anak Untuk
Siswa Sekolah Dasar. Dharma Raflesia Unib Tahun XVII. 2019;2:1-6.

30. Panjaitan RL, Djuanda D, Hanifah N. Persepsi Guru Mengenai Sex Education Di Sekolah Dasar Kelas VI. Univ Pendidik Indones. 2015;2(2):22433.

31. Permatasari E, Adi GS. Gambaran Pemahaman Anak Usia Sekolah Dasar Tentang Pendidikan Seksual Dalam Upaya Pencegahan Kekerasan Seksual Pada Anak. Indones J Heal Sci. 2017;9(1).

32. Makmur, Sujana T, Kinasih A. Strategi Program Kesehatan Puskesmas Di Sekolah Dasar. J Ilmu Keperawatan dan Kebidanan. 2017;8(2):107-13.

33. Fauziyah A. Pengaruh Pendidikan Kesehatan Tentang Nutrisi Prakonsepsi Terhadap Tingkat Pengetahuan, Sikap, Dan Praktik Konsumsi Makanan Sehat Wanita Pranikah. 2012;

34. Pahliwandari R. Penerapan Teori Pembelajaran Kognitif Dalam Pembelajaran Pendidikan Jasmani dan Kesehatan. J Pendidik Olahraga. 2016;5:15464.

35. Kastleman MB. The Drug of The New Millennium (Narkoba Milenium Baru) Penjelasan Ilmiah Tentang Cara Pornografi di Internet Dapat Mengubah Otak Manusia Secara Radikal. 2016. $17-27 \mathrm{p}$.

36. Luthfi M. Efektivitas Penerapan Metode Qissatu Al-Qurani Untuk Meningkatkan Akhlak Mulia Siswa Kelas IV SD Cirebon Islamic School (CIS) Full Day. J Pendidik Islam. 2018;9:153-65. 